NASA/TM-2004-213401

\title{
Performance Characterization of a Lithium-Ion Gel Polymer Battery Power Supply System for an Unmanned Aerial Vehicle
}

Concha M. Reid and Michelle A. Manzo

Glenn Research Center, Cleveland, Ohio

Michael J. Logan

Langley Research Center, Hampton, Virginia 
Since its founding, NASA has been dedicated to the advancement of aeronautics and space science. The NASA Scientific and Technical Information (STI) Program Office plays a key part in helping NASA maintain this important role.

The NASA STI Program Office is operated by Langley Research Center, the Lead Center for NASA's scientific and technical information. The NASA STI Program Office provides access to the NASA STI Database, the largest collection of aeronautical and space science STI in the world. The Program Office is also NASA's institutional mechanism for disseminating the results of its research and development activities. These results are published by NASA in the NASA STI Report Series, which includes the following report types:

- TECHNICAL PUBLICATION. Reports of completed research or a major significant phase of research that present the results of NASA programs and include extensive data or theoretical analysis. Includes compilations of significant scientific and technical data and information deemed to be of continuing reference value. NASA's counterpart of peerreviewed formal professional papers but has less stringent limitations on manuscript length and extent of graphic presentations.

- TECHNICAL MEMORANDUM. Scientific and technical findings that are preliminary or of specialized interest, e.g., quick release reports, working papers, and bibliographies that contain minimal annotation. Does not contain extensive analysis.

- CONTRACTOR REPORT. Scientific and technical findings by NASA-sponsored contractors and grantees.
- CONFERENCE PUBLICATION. Collected papers from scientific and technical conferences, symposia, seminars, or other meetings sponsored or cosponsored by NASA.

- SPECIAL PUBLICATION. Scientific, technical, or historical information from NASA programs, projects, and missions, often concerned with subjects having substantial public interest.

- TECHNICAL TRANSLATION. Englishlanguage translations of foreign scientific and technical material pertinent to NASA's mission.

Specialized services that complement the STI Program Office's diverse offerings include creating custom thesauri, building customized databases, organizing and publishing research results ... even providing videos.

For more information about the NASA STI Program Office, see the following:

- Access the NASA STI Program Home Page at http://www.sti.nasa.gov

- E-mail your question via the Internet to help@sti.nasa.gov

- Fax your question to the NASA Access Help Desk at 301-621-0134

- Telephone the NASA Access Help Desk at 301-621-0390

- Write to:

NASA Access Help Desk

NASA Center for AeroSpace Information 7121 Standard Drive

Hanover, MD 21076 
NASA/TM-2004-213401

\section{Performance Characterization of a Lithium-Ion Gel Polymer Battery Power Supply System for an Unmanned Aerial Vehicle}

Concha M. Reid and Michelle A. Manzo

Glenn Research Center, Cleveland, Ohio

Michael J. Logan

Langley Research Center, Hampton, Virginia

Prepared for the

Power Systems Conference

sponsored by the Society of Automotive Engineers

Reno, Nevada, November 2-4, 2004

National Aeronautics and

Space Administration

Glenn Research Center 


\section{Acknowledgments}

Cells for testing were provided to the NASA Glenn Research Center by the NASA Langley Research Center. This work was performed under the NASA Aerospace Flight Battery Systems program funded through the Energetics Project of NASA's Code R (Aerospace Technology).

This report contains preliminary

findings, subject to revision as analysis proceeds.

Available from

NASA Center for Aerospace Information 7121 Standard Drive

Hanover, MD 21076
National Technical Information Service 5285 Port Royal Road Springfield, VA 22100 


\title{
Performance Characterization of a Lithium-Ion Gel Polymer Battery Power Supply System for an Unmanned Aerial Vehicle
}

\author{
Concha M. Reid and Michelle A. Manzo \\ National Aeronautics and Space Administration \\ Glenn Research Center \\ Cleveland, Ohio 44135 \\ Michael J. Logan \\ National Aeronautics and Space Administration \\ Langley Research Center \\ Hampton, Virginia 23681
}

\begin{abstract}
Unmanned aerial vehicles (UAVs) are currently under development for NASA missions, earth sciences, aeronautics, the military, and commercial applications. The design of an all electric power and propulsion system for small UAVs was the focus of a detailed study. Currently, many of these small vehicles are powered by primary (nonrechargeable) lithium-based batteries. While this type of battery is capable of satisfying some of the mission needs, a secondary (rechargeable) battery power supply system that can provide the same functionality as the current system at the same or lower system mass and volume is desired. A study of commercially available secondary battery cell technologies that could provide the desired performance characteristics was performed. Due to the strict mass limitations and wide operating temperature requirements of small UAVs, the only viable cell chemistries were determined to be lithium-ion liquid electrolyte systems and lithium-ion gel polymer electrolyte systems.
\end{abstract}

Two lithium-ion gel polymer cell designs were selected as candidates and were tested using potential load profiles for UAV applications. Because lithium primary batteries have a higher specific energy and energy density, for the same mass and volume allocation, the secondary batteries resulted in shorter flight times than the primary batteries typically provide. When the batteries were operated at lower ambient temperatures $\left(0\right.$ to $-20{ }^{\circ} \mathrm{C}$ ), flight times were even further reduced. Despite the reduced flight times demonstrated, for certain UAV applications, the secondary batteries operated within the acceptable range of flight times at room temperature and above.

The results of this testing indicate that a secondary battery power supply system can provide some benefits over the primary battery power supply system. A UAV can be operated for hundreds of flights using a secondary battery power supply system that provides the combined benefits of rechargeability and an inherently safer chemistry.

\section{INTRODUCTION}

Unmanned aerial vehicles (UAVs) are currently under development for NASA missions, earth sciences, aeronautics, the military, and commercial applications [1][2][3]. This paper focuses on the design of an all electric power system for two typical small UAVs, such as the one pictured in Figure 1 that was designed and built at the NASA Small Unmanned Aerial Vehicle Laboratory (SUAVELab) at NASA Langley Research Center.

Currently, many small UAVs are powered by a primary lithium-based battery. While this type of battery is capable of satisfying the basic mission needs, the inability to reuse the battery presents some limitations. In order for one primary battery to enable multiple flights, a much larger battery would be required. Such a system would be prohibitive in terms of mass and volume.

In order to provide a more convenient and affordable source of energy, a commercial-off-the-shelf (COTS) secondary battery power supply system that can provide the same functionality as the current system at the same or lower system mass and volume is desired. A COTS battery is desired because it provides the advantages of being readily available, being lower cost than custom built cells, and being of virtually unlimited supply [4].

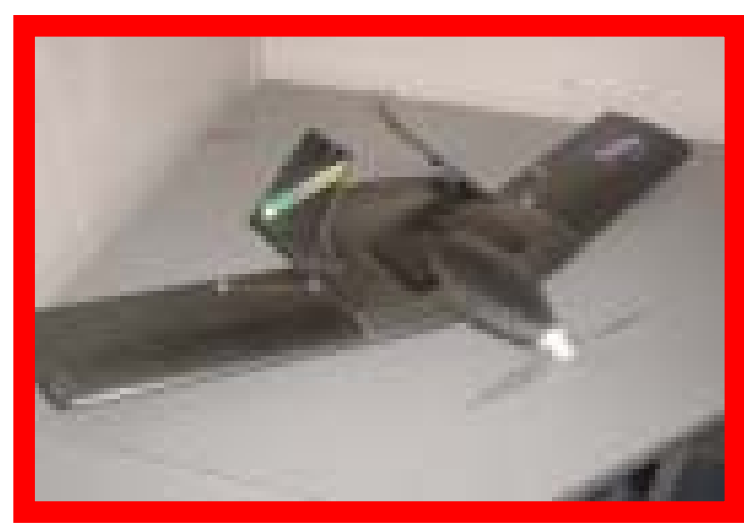

Figure 1: A "Man-Portable" Small UAV Source: SUAVELab at NASA Langley Research Center 
Two batteries consisting of secondary lithium-based cells were constructed and tested to determine the feasibility of utilizing this type of power system for this application. Both power supply systems were tested for their ability to meet selected load profiles. A life test was also performed using one cell pack in order to assess its ability to provide the power for the desired number of flights.

\section{BACKGROUND}

Designing a power system for a UAV that consists of secondary cells presents certain challenges. The power system must be lightweight in order to reduce the induced drag penalty caused by adding mass to an aircraft [5]. This presents a challenge for secondary battery systems that are being considered as replacements of primaries because primary lithiumbased cells have higher specific energy and can therefore enable lower mass electric power systems and longer flight times. Trade-offs are inevitable between the benefits of longer flight times and lower weight systems and the benefits a secondary system provides, such as rechargeability and an inherently safer chemistry.

In this paper, we will discuss batteries for an electric power system for two types of UAVs, a fixed wing aircraft and a vertical takeoff and landing (VTOL) aircraft. Table 1 shows the general specifications for these systems. The fixed-wing UAV design is a bungee-launched system. Electric power is only necessary for the cruise portion of the flight. For this exercise, we will assume a flat base load profile of a given power level and duration during cruising. After cruising, the aircraft glides into its landing.

The VTOL aircraft requires a much higher power draw at take-off and landing; 2.5 times that used for cruising. For the VTOL UAV, we will again assume a flat base load profile of a given power level and duration during cruising. We will also assume a peak pulse of a given duration at the beginning of the flight for take-off and another at the end for landing.

Landing will present a tremendous strain on the power system as the battery must provide a long pulse at peak power at the end of discharge when it is operating at lower voltage. In order to achieve this high pulse, flight time is greatly reduced to ensure that the battery can deliver the power required to land the aircraft.

The baseline power system consists of a primary battery that can achieve a given flight time at room temperature. Testing of candidate cells for the application will determine the length of time the aircraft can sustain the desired speeds at various temperatures with an alternate secondary battery power supply system.
Table 1: Power Requirements

\begin{tabular}{|l|l|l|}
\hline Cruise Power & Fixed Wing UAV & \multicolumn{1}{|c|}{$\begin{array}{l}\text { Vertical Take-Off } \\
\text { and Landing UAV }\end{array}$} \\
\hline $\begin{array}{l}\text { Take-off and } \\
\text { Landing Power }\end{array}$ & None & Y watts at Z volts $Z$ volts \\
\hline Mass & $\begin{array}{l}\text { No more than } 1 / 10 \\
\text { the mass of the } \\
\text { aircraft }\end{array}$ & $\begin{array}{l}\text { No more than } 1 / 10 \\
\text { the mass of the } \\
\text { aircraft }\end{array}$ \\
\hline $\begin{array}{l}\text { Operating } \\
\text { Temperature }\end{array}$ & $\begin{array}{l}-20 \text { to } 120^{\circ} \mathrm{F} \\
\left(-29 \text { to } 49^{\circ} \mathrm{C}\right)\end{array}$ & $\begin{array}{l}-20 \text { to } 120^{\circ} \mathrm{F} \\
\left(-29 \text { to } 49^{\circ} \mathrm{C}\right)\end{array}$ \\
\hline Other & $\begin{array}{l}\text { COTS rechargeable } \\
\text { batteries, must } \\
\text { provide } 100 \text { cycles } \\
\text { over two years }\end{array}$ & $\begin{array}{l}\text { COTS rechargeable } \\
\text { batteries, must } \\
\text { provide } 100 \text { cycles } \\
\text { over two years }\end{array}$ \\
\hline
\end{tabular}

\section{GENERAL DESIGN}

Once the requirements of the electric power systems for the UAVs were defined, the capabilities of the battery systems that could satisfy the power requirements were identified. After the minimum specifications were determined, a survey was performed to identify specific battery chemistries that could meet the need.

Lithium-based batteries were identified as the chemistry of choice due to their high specific energy and energy density as compared to other battery chemistries. Additional features of this chemistry are its ability to operate over wide temperature ranges and its high operating voltage. Lithium-based cells operate at a higher voltage than other cell chemistries, so fewer cells are necessary to meet the voltage requirement. Given the high peak power requirement, it was also desirable to choose a lithium-based cell that was capable of cycling at a high rate.

\section{CELL SELECTION}

A survey of commercially available (COTS) lithiumbased cells was performed and several promising candidates were identified. Preliminary calculations, based on manufacturer data, revealed those cells that were capable of meeting the load profile and delivering the longest flight times within the mass allocation.

Two designs of lithium-ion liquid electrolyte cells and four designs of lithium-ion gel polymer cells from various lithium-based battery manufacturers were identified as candidates to replace the primary batteries.

Ultimately, two cell designs were selected for the project. These cells will be designated as cell $A 1$ and cell $A 2$. Cell $A 1$ is an 880 milliampere-hour (mAh) lithium-ion gel 
Table 2: Manufacturer Cell Specifications

\begin{tabular}{|l|c|c|}
\hline & Cell A1 & Cell A2 \\
\hline Nameplate Capacity & $880 \mathrm{mAh}$ & $3180 \mathrm{mAh}$ \\
\hline $\begin{array}{l}\text { Average Cell Voltage } \\
\text { at C/2 Rate }\end{array}$ & $3.7 \mathrm{~V}$ & $3.7 \mathrm{~V}$ \\
\hline Cell Voltage Limits & 3.0 to $4.2 \mathrm{~V}$ & 3.0 to $4.2 \mathrm{~V}$ \\
\hline $\begin{array}{l}\text { Maximum Continuous } \\
\text { Discharge Rate }\end{array}$ & $2 \mathrm{C}$ & $2 \mathrm{C}$ \\
\hline Approximate Mass & $18 \mathrm{~g}$ & $64 \mathrm{~g}$ \\
\hline Specific Energy & $187 \mathrm{Wh} / \mathrm{kg}$ & $190 \mathrm{Wh} / \mathrm{kg}$ \\
\hline Energy Density & $366 \mathrm{Wh} / \mathrm{L}$ & $386 \mathrm{Wh} / \mathrm{L}$ \\
\hline
\end{tabular}

polymer cell. Cell A2 is a $3180 \mathrm{mAh}$ lithium-ion gel polymer cell. Due to the ability of these cell designs to deliver relatively high rate currents to meet the peak loads, and the small amount of additional capacity required during these relatively short pulses, the same cells are used for both types of load profiles. Two battery systems were configured to meet both applications, one constructed from A1 cells and the other constructed from A2 cells.

Manufacturer specifications for the chosen cells are given in Table 2. The energy density and specific energy are calculated for a $\mathrm{C} / 2$ discharge at $100 \%$ DOD at 20 ${ }^{\circ} \mathrm{C}$ using a 3.7 volt $(\mathrm{V})$ average discharge voltage.

\section{EXPERIMENTAL TEST RESULTS}

The two lithium-ion gel polymer cell designs that were selected were tested for capacity and performance using the potential load profiles for the UAV applications. All testing was performed in-house at NASA Glenn Research Center in the Electrochemical Cell and Battery Test Facility of the Power and On-Board Propulsion Technology Division.

\section{CAPACITY}

Capacity tests were performed on battery cells A1 and A2 to verify manufacturer results and to characterize performance as a function of voltage effects. Characterization tests were performed using a constant current discharge to 3.0 volts. Cells were charged at a $\mathrm{C} / 2$ rate to 4.2 volts. The voltage was then held constant and the current was allowed to taper to C/50 amperes. Charges were conducted at the desired operating temperature, except for the $-20{ }^{\circ} \mathrm{C}$ case. Because the cell chemistry could not support charging at $-20{ }^{\circ} \mathrm{C}$ the cells were charged at $0{ }^{\circ} \mathrm{C}$. Cells were soaked at test temperature for a minimum of two hours before charging or discharging.
Tables 3 and 4 show capacity delivered for each cell design at different conditions. Figures 2 and 3 illustrate voltage versus discharge capacity for cell $\mathrm{A} 2$ at a $2 \mathrm{C}$ rate at multiple temperatures and at $45{ }^{\circ} \mathrm{C}$ at multiple discharge rates, respectively.

At $-20{ }^{\circ} \mathrm{C}$ and a $2 \mathrm{C}$ or higher discharge rate, the cells could not sustain discharge for any significant amount of time, so they delivered virtually no capacity in these cases. It can be determined by observing the capacity delivered at $2 \mathrm{C}$ that the final battery system will perform best under the $23{ }^{\circ} \mathrm{C}$ (room temperature) and $45{ }^{\circ} \mathrm{C}$ temperature regimes.

These COTS cells exhibited reduced capacity at high rates or low temperatures. In both of these cases, the average voltage during discharge is also much lower than at the lower rates and moderate temperatures, as indicated by the very steep slopes. High rate COTS cells that could deliver a high proportion of the baseline $\mathrm{C} / 2$ capacity at high rates and still meet the other power system requirements were not identified during a study of commercial technology. In addition, it is difficult for the same cell to operate over such a wide operating temperature range. Lithium-based cells containing specially formulated low temperature electrolytes may garner better performance if it is known that the specific mission will require the UAV to operate at these low temperature extremes [6-8].

Table 3: Cell A1 Capacity at Different Temperatures

\begin{tabular}{|c|c|c|c|c|c|c|c|c|}
\hline \multicolumn{9}{|c|}{ Temperature $\left({ }^{\circ} \mathrm{C}\right)$} \\
\hline & \multicolumn{2}{|c|}{-20} & \multicolumn{2}{|c|}{0} & \multicolumn{2}{|c|}{23} & \multicolumn{2}{|c|}{45} \\
\hline Rate & Cap & MDV & Cap & MDV & Cap & MDV & Cap & MDV \\
\hline $\mathrm{C} / 5$ & 614 & 3.2 & 799 & 3.6 & * & * & 872 & 3.8 \\
\hline $\mathrm{C} / 2$ & * & * & * & * & 861 & 3.7 & * & * \\
\hline C & 15 & ** & 480 & 3.2 & * & * & 851 & 3.5 \\
\hline $2 \mathrm{C}$ & 0.1 & ** & 58 & 3.2 & * & * & 772 & 3.2 \\
\hline $5 \mathrm{C}$ & $\mathrm{ng}$ & ** & $\mathrm{ng}$ & ** & 77 & 3.4 & 287 & 3.4 \\
\hline
\end{tabular}

Cap = capacity in milliampere-hours, MDV = Mid-discharge voltage in volts, $\mathrm{ng}=$ negligible, ${ }^{*}=$ Proprietary manufacturer data

${ }^{* *}=$ Discharge time too rapid to record

Table 4: Cell A2 Capacity at Different Temperatures

\begin{tabular}{|c|c|c|c|c|c|c|c|c|}
\hline \multicolumn{9}{|c|}{ Temperature $\left({ }^{\circ} \mathrm{C}\right)$} \\
\hline & \multicolumn{2}{|c|}{-20} & \multicolumn{2}{|c|}{0} & \multicolumn{2}{|c|}{23} & \multicolumn{2}{|c|}{45} \\
\hline Rate & Cap & MDV & Cap & MDV & Cap & MDV & Cap & MDV \\
\hline $\mathrm{C} / 5$ & 2576 & 3.3 & 3030 & 3.7 & * & * & 3304 & 3.8 \\
\hline $\mathrm{C} / 2$ & * & * & * & * & 3250 & 3.7 & * & * \\
\hline $\mathrm{C}$ & 147 & 3.1 & 2684 & 3.3 & * & * & 3285 & 3.7 \\
\hline 2C & 0.9 & ** & 864 & 3.2 & 2717 & 3.5 & 3151 & 3.6 \\
\hline $5 \mathrm{C}$ & 0.04 & ** & 128 & 3.1 & 433 & 3.4 & 1375 & 3.5 \\
\hline
\end{tabular}

Cap = capacity in milliampere-hours, MDV = Mid-discharge voltage in volts, $\mathrm{ng}=$ negligible, ${ }^{*}=$ Proprietary manufacturer data

${ }^{* *}=$ Discharge time too rapid to record 


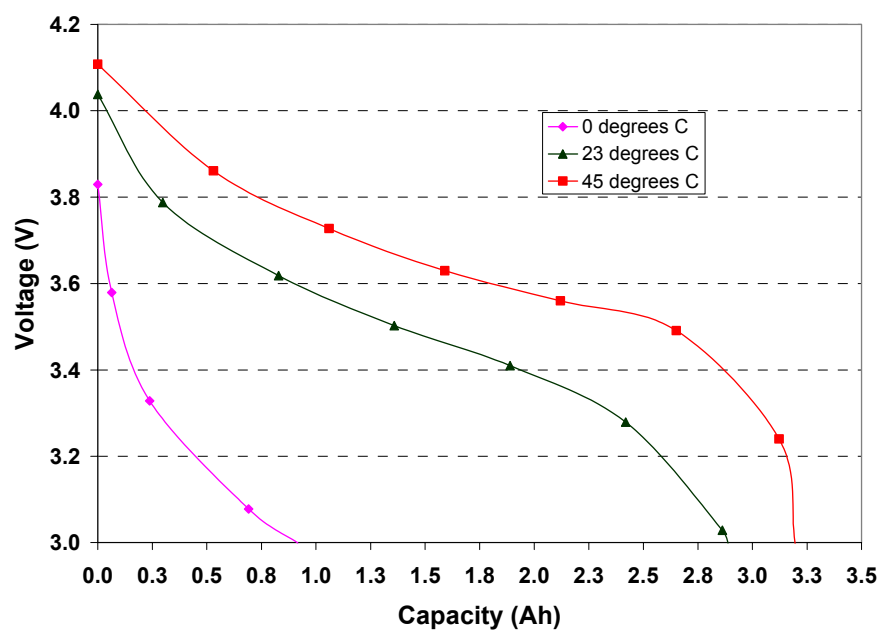

Figure 2: Discharge Capacity Curves at 2C Rate for Cell A2 at Different Ambient Temperatures

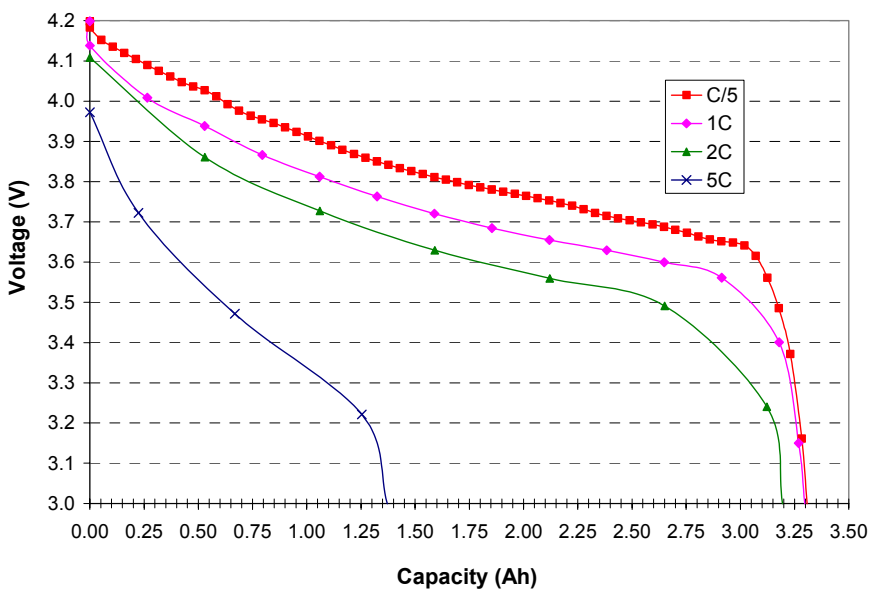

Figure 3: Discharge Curves at $45^{\circ} \mathrm{C}$ for Cell A2 at Different Rates

Once initial capacity was determined, cells were then electrically combined in series to represent a scaled down version of the final battery design that meets the mass limitation of the final battery system. Note that this scaling does not account for the mass of wiring or other necessary battery system peripherals. These items add mass and volume and would therefore need to be within the battery system mass and volume allocation when designing the actual system. The actual size and configuration of the test pack are shown in Table 5.

\section{LOAD PROFILES}

Constant power discharges were performed at scaled down discharge power rates that are representative of actual power system operation. For the fixed-wing test cases, the battery was discharged until the battery voltage reached $6 \mathrm{~V}$ or the first cell reached $3 \mathrm{~V}$. The equivalent flight times were evaluated by the discharge times. The baseline flight time is defined as the flight time that can be achieved by the existing primary battery system at room temperature.

NASA/TM-2004-213401
Table 5: Scaling of Cells for Testing

\begin{tabular}{|l|c|c|}
\hline & $\begin{array}{c}\text { Cell A1 Test } \\
\text { Conditions }\end{array}$ & $\begin{array}{c}\text { Cell A2 Test } \\
\text { Conditions }\end{array}$ \\
\hline Number of cells & 2 & 2 \\
\hline Cell configuration & 2 in series & 2 in series \\
\hline Mass of cells $\mathbf{( g )}$ & 37 & 131 \\
\hline $\begin{array}{l}\text { Volume of cells } \\
\text { (mL) }\end{array}$ & 25 & 77 \\
\hline $\begin{array}{l}\text { Operating voltage } \\
\text { range (V) }\end{array}$ & 8.4 to 6.0 & 8.4 to 6.0 \\
\hline
\end{tabular}

Table 6: Fixed Wing Load Profile Experimental Results

\begin{tabular}{|c|l|l|}
\hline Temperature $\left({ }^{\circ} \mathbf{C}\right)$ & \multicolumn{1}{|c|}{ A1 Cells } & \multicolumn{1}{c|}{ A2 Cells } \\
\hline $\mathbf{2 0}$ & $\begin{array}{l}\text { Flew for 9\% of } \\
\text { baseline flight time }\end{array}$ & $\begin{array}{l}\text { Flew for } 1 \% \text { of } \\
\text { baseline flight time }\end{array}$ \\
\hline $\mathbf{0}$ & $\begin{array}{l}\text { Flew for } 64 \% \text { of } \\
\text { baseline flight time }\end{array}$ & $\begin{array}{l}\text { Flew for } 80 \% \text { of } \\
\text { baseline flight time }\end{array}$ \\
\hline $\mathbf{2 3}$ & $\begin{array}{l}\text { Met baseline flight } \\
\text { time }\end{array}$ & $\begin{array}{l}\text { Met baseline flight } \\
\text { time }\end{array}$ \\
\hline $\mathbf{4 5}$ & $\begin{array}{l}\text { Met baseline flight } \\
\text { time }\end{array}$ & $\begin{array}{l}\text { Met baseline flight } \\
\text { time }\end{array}$ \\
\hline
\end{tabular}

Table 7: VTOL Load Profile Experimental Results

\begin{tabular}{|c|l|l|}
\hline Temperature $\left(^{\circ} \mathbf{C}\right)$ & \multicolumn{1}{|c|}{ A1 Cells } & \multicolumn{1}{c|}{ A2 Cells } \\
\hline 23 & $\begin{array}{l}\text { Flew for } 67 \% \text { of } \\
\text { baseline flight time }\end{array}$ & $\begin{array}{l}\text { Flew for } 78 \% \text { of } \\
\text { baseline flight time }\end{array}$ \\
\hline
\end{tabular}

The batteries were operated at $100 \%$ depth-of-discharge (DOD) during laboratory testing. Operating at 100\% DOD results in a slight decrease in flight time with each subsequent flight as battery capacity is reduced, therefore, an actual system would operate at a lower DOD. While this would slightly decrease the flight times that could be achieved during the initial flights, as a trade-off, the UAV will be able to achieve a consistent flight duration over a specified number of flights. Experimental test results for the fixed-wing UAV are shown in Table 6.

For the VTOL test case, the lower power discharge times (corresponding to power during cruise) were begun at 15 minutes in length and were stepped up incrementally in 5 minute intervals until the battery could no longer deliver the ending peak pulse for the full required duration to an end-of-discharge battery voltage of $6 \mathrm{~V}$ or $3 \mathrm{~V}$ on any cell. Cruise times were determined experimentally by the length of the longest low power discharge. Experimental test results for the VTOL UAV are shown in Table 7.

Because lithium primary batteries have a higher specific energy and energy density, for the same mass and volume allocation, the secondary batteries resulted in shorter flight times than the primary batteries typically provide. For the fixed-wing application, the secondary batteries operated within the acceptable range of flight durations at room temperature and above, however, when these batteries were operated in lower ambient 
temperatures $\left(0\right.$ to $\left.-20{ }^{\circ} \mathrm{C}\right)$, flight times were sometimes dramatically reduced. Lithium-ion gel polymer cells typically exhibit poor conductivity at low temperatures. This is a major limitation for this type of battery system when it may be required to operate at low ambient temperatures.

The A1 battery performs longer for the fixed-wing application with only a small mass penalty over the larger cells. The cells should fit easily within the mass allocation for either application.

The A2 battery performs slightly longer for the VTOL application. However, it is not possible to position these particular cells in the volume allocated for the VTOL application due to the dimensions of the space. With some creative positioning, the required number of cells can fit in the space allocated for the fixed wing application. Lithium-ion technology is capable of delivering the required energy within the volume allocation for both applications. The volume limitations noted for the VTOL case were due to the restrictions of a fixed cell size.

Longer flight times could be achieved if more of the craft mass was allocated for the power system. However, this would affect the lift-to-drag ratio (L/D ratio) and might impact other areas of aircraft performance.

During the testing, it was observed that cell temperatures increased 4 to $5{ }^{\circ} \mathrm{C}$ during discharge periods. Since lithium-ion gel polymer cells emit heat during high rate discharges, the thermal interactions of a large quantity of cells configured into a battery may help to increase performance by simulating a warmer ambient temperature. The effect of stack size plays a significant role in the thermal behavior of this type of cell [9].

Table 8: Life Test Results for A1 battery using Fixed Wing Load Profile

\begin{tabular}{|c|c|}
\hline Cycle number & $\begin{array}{c}\text { Percent of capacity delivered as compared } \\
\text { to first life test cycle }\end{array}$ \\
\hline 1 & 100 \\
\hline 5 & 98.6 \\
\hline 10 & 96.9 \\
\hline 25 & 95.6 \\
\hline 50 & 95.1 \\
\hline 75 & 92.9 \\
\hline 100 & 92.3 \\
\hline 125 & 91.6 \\
\hline 150 & 90.8 \\
\hline
\end{tabular}


Custom-designed cells using existing technology could extend the performance and provide some level of assurance of consistency in the product's performance. They could also offer more flexible packaging options in order to maximize the energy that can be provided in the available volume.

While COTS cells have their advantages, they also have several disadvantages [11]. First, they cannot be customized for specific missions that may require high current rates or higher or lower temperature operation. Second, the consumer does not have the ability to ensure manufacturing consistency so that cell performance is the same every time. Third, COTS cells may not be suited for a UAV application that requires the battery to conform into unusual configurations that may be impossible to achieve with predetermined cell packaging.

In all cases discussed in this paper, battery performance is greatly decreased at and below $0{ }^{\circ} \mathrm{C}$. Several options also exist to increase low temperature performance. These include the selection of a cell design that is specially formulated to perform at high rates over a wide range of temperatures, utilizing a cell design with an electrolyte that operates over a wider temperature range, such as a lithium-based liquid electrolyte system, and discharging battery to a lower voltage at low temperatures if the minimum voltage for the load profile has not been reached.

\section{CONCLUSIONS}

A lithium-ion gel polymer battery power supply system can operate a UAV for over 150 flights. A lithium-based secondary battery system provides the combined benefits of rechargeability and an inherently safer chemistry over a primary battery system. As secondary lithium-based battery systems evolve further, leak-proof, conformable true polymer batteries may be a reality, which will increase the margin of safety even further and provide flexibility in positioning the battery on crafts where volume is a major constraint.

\section{REFERENCES}

1. Baldwin, R.S., Manzo, M.A., Dalton, P.J., Marsh, R.A., and Surampudi, R., "Polymer Energy Rechargeable System (PERS) Development Program," NASA/TM-2001-210217, NASA Glenn Research Center, Cleveland, OH, May 2001.
2. Pérez-Davis, M.E., Loyselle, P.L., Hoberecht, M.A., Manzo, M.A., Kohout, L.L., Burke, K.A., and Cabrera, Carlos, "Energy Storage for Aerospace Applications," NASA/TM-2001-211068, NASA Glenn Research Center, July, 2001.

3. Marsh, R.A., Vukson, S., Surampudi, S., Ratnakumar, B.V., Smart, M.C., Manzo, M., and Dalton, P.J., "Li ion Batteries for Aerospace Applications," Journal of Power Sources, v 97-98, 2001, pp. 25-27.

4. Govar, C.J. and Squires, T.L., "Safety Tests of Lithium 9-Volt Batteries for Navy Applications," IEEE AESS Systems Magazine, September, 2001, pp. 34-37.

5. Understanding Flight - An Introduction to Aeronautics, Course Notes, Hallgren Associates, Inc., Monument, Colorado, Fall 2003.

6. Smart, M.C., Huang, C.K., Ratnakumar, B.V., and Surampudi, S., "Development of Advanced Lithiumion Cells with Improved Low Temperature Performance," Proceedings of the Intersociety Energy Conversion Engineering Conference (IECEC), Honolulu, Hawaii, July 1997.

7. Smart, M.C., Ratnakumar, B.V., and Surampudi, S., "Electrolytes for Low Temperature Lithium-Ion Batteries Based on Mixtures of Aliphatic Carbonates," Journal of the Electrochemical Society, v 146, 1999, pp. 486-492.

8. Salomon, M., Lin, H., Plichta, E.J., and Hendrickson, M., "Temperature Effects on Li-lon Cell Performance," in van Schalkwijk, W. and Scrosati, B., Advances in Lithium Ion Batteries, Kluwer Academic/Plenam Publishers, New York, 2002, pp. 309-344.

9. Chen, Y. and Evans, J.W., "Thermal Analysis of Lithium Polymer Electrolyte Batteries by a Two Dimensional Model-Thermal Behavior and Design Optimization," Electrochimica Acta, v 39, n 4, 1994, pp. 517-526.

10. Spotnitz, R., "Scale-up of Lithium-Ion Cells and Batteries," in van Schalkwijk, W. and Scrosati, B., Advances in Lithium lon Batteries, Kluwer Academic/Plenam Publishers, New York, 2002, pp. 433-457.

11. Banner, J.A., Barnes, J.A., and Winchester, C.S., "Continuing Challenges in Lithium Battery Development," IEEE AESS Systems Magazine, May 2000, pp. 31-33. 
Public reporting burden for this collection of information is estimated to average 1 hour per response, including the time for reviewing instructions, searching existing data sources, gathering and maintaining the data needed, and completing and reviewing the collection of information. Send comments regarding this burden estimate or any other aspect of this collection of information, including suggestions for reducing this burden, to Washington Headquarters Services, Directorate for Information Operations and Reports, 1215 Jefferson Davis Highway, Suite 1204, Arlington, VA 22202-4302, and to the Office of Management and Budget, Paperwork Reduction Project (0704-0188), Washington, DC 20503.

\begin{tabular}{|l|l|l}
\hline 1. AGENCY USE ONLY (Leave blank) & $\begin{array}{c}\text { 2. REPORT DATE } \\
\text { November } 2004\end{array}$ & $\begin{array}{r}\text { 3. REPORT TYPE AND DATES COVERED } \\
\text { Technical Memorandum }\end{array}$ \\
\hline
\end{tabular}

\section{TITLE AND SUBTITLE}

Performance Characterization of a Lithium-Ion Gel Polymer Battery Power Supply System for an Unmanned Aerial Vehicle

6. AUTHOR(S)

Concha M. Reid, Michelle A. Manzo, and Michael J. Logan

\section{FUNDING NUMBERS}

WBS-22-319-20-L1

\section{PERFORMING ORGANIZATION NAME(S) AND ADDRESS(ES)}

National Aeronautics and Space Administration

John H. Glenn Research Center at Lewis Field

Cleveland, Ohio 44135-3191
8. PERFORMING ORGANIZATION REPORT NUMBER

E-14907

\section{SPONSORING/MONITORING AGENCY NAME(S) AND ADDRESS(ES)}

National Aeronautics and Space Administration

Washington, DC 20546-0001

10. SPONSORING/MONITORING AGENCY REPORT NUMBER

NASA TM-2004-213401

2004-01-3166

\section{SUPPLEMENTARY NOTES}

Prepared for the Power Systems Conference sponsored by the Society of Automotive Engineers, Reno, Nevada, November 2-4, 2004. Concha M. Reid and Michelle A. Manzo, NASA Glenn Research Center; and Michael J. Logan, NASA Langley Research Center. Responsible person, Concha M. Reid, organization code RPC, 216-433-8943.

12a. DISTRIBUTION/AVAILABILITY STATEMENT 12b. DISTRIBUTION CODE

Unclassified - Unlimited

Subject Categories: 07, 28, and 44

Distribution: Nonstandard

Available electronically at http://gltrs.grc.nasa.gov

This publication is available from the NASA Center for AeroSpace Information, 301-621-0390.

\section{ABSTRACT (Maximum 200 words)}

Unmanned aerial vehicles (UAVs) are currently under development for NASA missions, earth sciences, aeronautics, the military, and commercial applications. The design of an all electric power and propulsion system for small UAVs was the focus of a detailed study. Currently, many of these small vehicles are powered by primary (nonrechargeable) lithium-based batteries. While this type of battery is capable of satisfying some of the mission needs, a secondary (rechargeable) battery power supply system that can provide the same functionality as the current system at the same or lower system mass and volume is desired. A study of commercially available secondary battery cell technologies that could provide the desired performance characteristics was performed. Due to the strict mass limitations and wide operating temperature requirements of small UAVs, the only viable cell chemistries were determined to be lithium-ion liquid electrolyte systems and lithium-ion gel polymer electrolyte systems. Two lithium-ion gel polymer cell designs were selected as candidates and were tested using potential load profiles for UAV applications. Because lithium primary batteries have a higher specific energy and energy density, for the same mass and volume allocation, the secondary batteries resulted in shorter flight times than the primary batteries typically provide. When the batteries were operated at lower ambient temperatures $\left(0\right.$ to $\left.-20^{\circ} \mathrm{C}\right)$, flight times were even further reduced. Despite the reduced flight times demonstrated, for certain UAV applications, the secondary batteries operated within the acceptable range of flight times at room temperature and above. The results of this testing indicate that a secondary battery power supply system can provide some benefits over the primary battery power supply system. A UAV can be operated for hundreds of flights using a secondary battery power supply system that provides the combined benefits of rechargeability and an inherently safer chemistry.

\section{SUBJECT TERMS}

Lithium batteries; Storage batteries; Electric batteries; Electric power supplies; Aircraft

power supplies; Electric power; Light aircraft; Pilotless aircraft; Remotely piloted vehicles;

Electrochemical cells

17. SECURITY CLASSIFICATION OF REPORT

Unclassified

18. SECURITY CLASSIFICATION
OF THIS PAGE
Unclassified

Unclassified
15. NUMBER OF PAGES

12

16. PRICE CODE

20. LIMITATION OF ABSTRACT OF ABSTRACT

Unclassified 

